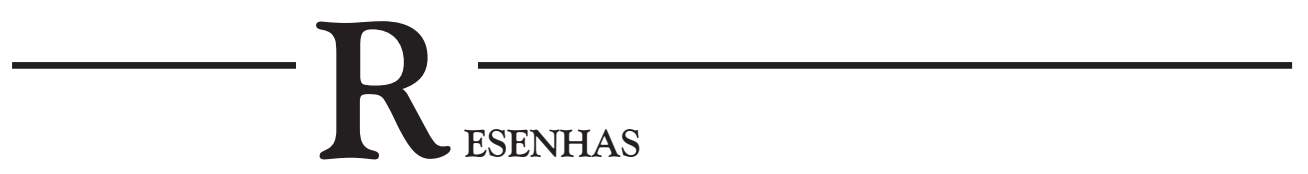

BRANDÃO, Carlos. Prece e Folia, Festa e Romaria. Aparecida/São Paulo: Ideias \& Letras, 2010, 228pp.

\title{
APRENDENDO COM OS MAIS VELHOS E ENSINANDO PARA OS MAIS JOVENS: FÉ E PEDAGOGIA DO CATOLICISMO POPULAR
}

\section{Larissa Geórgia Bráulio Moura Sheila Maria Doula}

É com odesejo de compreender sua própria fé, entremeada à fé da religiosidade popular, buscando significados para a crença das pessoas em Deus, que Brandão inicia as páginas desse complexo de histórias sobre as culturas religiosas populares brasileiras.

Procurando respostas para o porquê das crenças e indicando que talvez elas nem existam, ele nos convida a conhecer as mais diversas manifestações do catolicismo popular pelo paíse mostra, em cada capítulo, que perguntas como "que Deus ou quais deuses habitam ainda a pessoa individual ou coletiva de nós mesmos?"não podem ser traduzidas em palavras, mas podem ser vistas na Folga e na Folia, ou simplesmente, em cada um de nós, pelo modo (seja ele qual for) de concebermos ou manifestarmos nossa fé (:11).

Em uma trajetória de quarenta anos, Brandão tornou-se um especialista em antropologia rural e da religião, tendo centrado seus trabalhos no 
conhecimento de culturas populares, educação rural e educação popular. Percorreu diversos estados brasileiros, entre eles Goiás, Minas Gerais e São Paulo, pesquisando e relatando as mais diferentes histórias acerca da religiosidade no meio rural, que ainda hoje preserva e repassa para as novas gerações a tradição de uma vida dedicada à fé. A fé dentro de uma religião que, segundo o autor, é cheia de faces; um catolicismo que agrega e aceita diferentes formas de manifestações e que, apesar de ainda se vestir de uma roupagem tradicional, "reguladora e hierárquica" (...), se constitui em "uma das mais abertas e generosas religiões de nosso tempo" (:11).

A partir deste entendimento sobre o catolicismo, Brandão descreve em oito capítulos as manifestações dessa religião, revitalizada em folias, festas do divino, folgas e quaresma e que, segundo o autor, se misturam aos mais variados tipos do viver a fé. Pelos lugares por onde passou, Brandão encontrou igrejas e religiões opostas coexistindo entre si em uma "permanente interação entre asas efêmeras e errantes e raízes estáveis e fixas na terra e no coração das pessoas" que conheceu (:15). São exatamente essas contradições e complementaridades existentes entre o oficial e o chamado catolicismo popular que Prece e Folia, Festa e Romaria nos traz.

Os capítulos do livro registram o percurso de Brandão pelas festas religiosas rurais brasileiras por ele apresentadas como "celebração plural da fé" (:17). Segundo o autor, é no momento da festa e da celebração dos rituais que a envolvem, seja de conteúdo religioso ou profano (ou na mistura e complementaridade dos dois), que podemos fugir do cotidiano, inverter papéis, trocar afetos e sentidos, e, nas palavras do autor, "possamos dizer-nos uns aos outros e com ou sem a mediação do sagrado quem somos e por quê" (:27). Ademais, nessas festividades, as pessoas compartilham valores, símbolos, fé e reproduzem, muitas vezes, saberes de uma história popular que dá sentido às demais trocas sociais e que se afirmam por um conhecimento sem escolas e sem livros, processado pela sabedoria e pela memória de seus mestres.

Neste sentido, podemos encontrar no terceiro capítulo do livro de Brandão uma dissertação sobre aespecificidade da forma de educação praticada pelos mestres de Folga e Folia, através de inúmeras histórias acerca dos preceitos aprendidos e ensinados por eles, que atravessaram gerações e permanecem no âmbito de uma mesma família. São conhecimentos familiares que se tornam comunitários ao longo do tempo, poissurgem em um determinado lar, mas atravessam os muros das casas de seus tutores e tornam-se acervo e patrimônio local.

Assim, o conteúdo dessa educação,ao contrário da educação erudita, não pode ser encontrado em livros dispostos em bibliotecas disponíveis a todos, uma vez que essa forma de ensino encontra-se envolvida em uma trama social de trocas mais ampla, que confere sentidos e significados. Trata-se de um ritual 
que compreende um "trabalho social de transferência de conhecimento" (:16) - conhecimento que remete a raízes históricas, num tempo em que, ainda nas igrejas medievais e posteriormente coloniais, a religião católica era permeadade cantorias e danças renegadas à profanação, mas que ganharam as ruas das cidades e compuseram um novo modo de interação popular com a fé.

A dança e o canto da Folia passaram pelos "salões dos nobres", tornaramse "partes da vida das confrarias e irmandades religiosas de todo o país" (:42). Trazidos pelos jesuítas na forma de "dramas de piedade cristã", foram "aos poucos expulsos do interior dos templos" passando a compor os festejos de praça e de rua em uma nova roupagem, tornando-se características do chamado catolicismo popular (:42). A Folia, desse modo, passa a realizar-se como um trabalho religioso que sobrevive ao lado da religião oficial, podendo ser encontrada ainda hoje em pequenas cidades do interior dos estados brasileiros, principalmente em redutos de uma cultura que o autor classifica como camponesa. Trata-se, segundo Brandão, de uma forma de preservar e levar às comunidades rurais e urbanas "o saber coletivo de crenças de fé, ritos de piedade e regras de vida", através dos "viajeiros" (mestres, contramestres, foliões e folgazóes) da Folga e da Folia (:43).

$\mathrm{O}$ romantismo de Brandão nas páginas em diante indica a resposta à pergunta que ele mesmo havia feito no início do capítulo três - "(...) mestres da 'Folga' e da 'Folia' - saberemosouvi-los?" (:30). As histórias sobre aprendizado, tradição, passagem e ensinamentos imersos nas culturas popularesrevelam um mundo em que valores morais de respeito às crenças, à vida, a Deus e à família, ainda persistem, segundo Brandão, em muitos recantos do Brasil. $O$ autor defende que o trabalho de educação leiga busca justamente transmitir esses saberes para que os jovens possam assimilá-los e assim conservá-los. Esse caráter pedagógico do catolicismo popular pretende, dessa forma, repassar um conteúdo de cunho mais ontológico sobre porque devemos ter e manter a fé.

A repetição dos rituais religiosos tem também, segundo o autor, a mesma função educativa. Assim, as "Companhias de camponeses" jornadeiam em nome dos "Três Reis Santos" percorrendo estradas entre as casas dos crentes num longo rito recompondo a viagem que estes fizeram a Belém ${ }^{1}$. Compostas por mestres eleitos "de dom e divindade", a Folia cumpre o seu destino em um ritual que se reproduzano após ano:

(...) todos os momentos do foliar são codificados: caminhar pelas estradas; encontrar outras bandeiras (outras equipes de Folia) pelo caminho; entrar em cada casa de morador (na verdade, em cada um dos espaços nominados da casa, muitas vezes a porteira, o arco, a varanda, a sala); proceder dentro de cada casa, no interior e fora dos momentos propriamente religiosos do ritual; cantar e dançar nas casas de pouso; chegar ao local da festa e proceder ali (:45).

Auxiliada por um mestre responsável pelos saberes e ensinamentos, a Folia 
de Reis segue seu caminho, respeitando os lugares de "giro" e "pouso", amparando os festeiros em suas promessas e pedidos, cumprindo a "missão" que lhes foi delegada pelo "divino". Nessa perspectiva, o mestre assume, de acordo com Brandão, o papel de um "professor rústico" sobre quem recai a responsabilidade de compor um "grupo corporado de artistas-devotos" (como são chamados os foliões), transferindo a todos o seu saber. $O$ mestre deve ainda manter seus discípulos "coesos e submissos ao código do ritual", distribuindo a cada um o trabalho para a realização da Folia (:48).

Afunção é atribuída a cada um dos foliões de acordo com suas posições assumidas na Folia, o que nos leva a entender que essa forma de devoção obedece a princípios hierárquicos de comando, sendo estes, entretanto, delegados de acordo com a capacidade, o dom e a missão de cada um. Nesse sentido, a Folia de Reis apresenta-se como um exemplo, segundo o autor, "da maneira como a sociedade camponesa estabelece relações sociais e simbólicas entre categorias de suas pessoas e grupos, no interior da família, da parentela, da vizinhança, da comunidade" (:55).

A partir desse sistema de ordenação das funções que se estabelece pelo dom de cada folião e, em vista disso, do ensinamento diferenciado a cada um deles, Brandão considera que o rito religioso da Folia "recria, grandiosa e ao mesmo tempo afetivamente, a ordem das relações entre as pessoas; pais, filhos, irmãos, compadres, outros parentes, vizinhos e companheiros" (:57). O rito da Folia é ensinado aos meninos que desde pequenos acompanham as jornadas, aprendendo com os mais velhos o toque dos instrumentos e a importância da religião, para repetir quando for a hora.

Dessa forma, o aprendizado do saber requer trabalho. Começa na infância e obriga ao compromisso de "participar, gerenciar ou embaixar uma Folia durante alguns anos de vida, ou durante toda ela" (:92-93). Trata-se de um trabalho simbólico que passa a fazer parte das "estruturas sociais de trocas comunitárias do campesinato" (:134) e o reforço continuado junto aos mais jovens é o que garante a sucessão e a reprodução dessas estruturas.

Além das Folias, Brandão também analisa outras formas de devoção que conectam as pessoas através de um sentimento religioso de união, respeito à tradição e sacrifício: a quaresma e a semana santa. $O$ autorrelata os festejos da cidade de Pirenópolis - Goiás, onde é rememorada a história da morte de Jesus "como ela aconteceu", sendo a semana santa aí celebrada menos teatralizada, segundo sua avaliação (:152). Para ele os festejos da semana santa naquela cidade refletem "uma espécie coletiva de reverente devoção contrita", por "algo mais coletivamente pesado do que individualmente triste, regido por um insistente convite ao reconhecimento ('Foi por você, também')" (:152). Brandão conclui que em Pirenópolis os fiéis, mais do que apenas espectadores dos ritos litúrgicos, são participantes, pois vivem dia após dia os sacrifícios da quaresma que se completam na semana santa. 
No domingo da Ressurreição, quando têm início as festividades do Divino na cidade, Brandão considera que ficam evidentes as contradições do catolicismo. Ao contrário dos ritos de devoção entoados pelo padre, figura central nas celebrações da semana santa, a festa do Divino é partilhada "entre leigos católicos da cidade e da roça", sendo o sacerdote a figura menos importante. Em contraposição aos sacrifícios da quaresma, de penitências e privações dos prazeres da vida em solidariedade ao homem que morreu para nos salvar,e à semana santa, com seus rituais que relembram os momentos de dor passados por Jesus, Brandão interpreta a festa do Divino como sendo" regida pela alegria, pelo júbilo, pelo excesso de gastos, de festejos de ruas (...) e de disposições profanas ao prazer" (:153). O autor conclui, então, que essas festas mostram as diversas faces do catolicismo popular e que, embora celebradas em contraposição, elas não se anulam, não se excluem, não competem entre si.

Pode decepcionar a alguns leitores o fato de Brandão não responder explicitamente aos questionamentos propostos nas primeiras páginas de seu livro ou o seu entendimento de que o "voto" feito pelos que crêem em uma força maior não possui uma explicação científica, palpável. Mas ao registrar essas histórias de fé Brandão consegue captar códigos sociais de trocas simbólicas e de conhecimentos que compõem a matriz mais invisível das práticas cotidianas das pessoas. A influência da teoria de Mauss sobre a dádiva e a noção de pessoa é preponderante na sua interpretação sobre o catolicismo popular.

Prece e Folia, Festa e Romaria é um livro de linguagem poética, que sintetiza a própria trajetória do autor, sempre enamorado das manifestações religiosas brasileiras. Brandão, como antropólogo renomado e grande conhecedor das religiosidades populares nacionais, assume, a cada novo trabalho, que é um homem de ciência, mas também de fé. Uma fé que o leva a compartir o próprio discurso de pessoas de tantos recantos rurais do país que ele observou e entrevistou, e que não buscam respostas e nem o porquê de sua crença nas figuras sagradas e divinas. Elas apenas vivem "situações de trocas (...) através de símbolos e sentidos que a vida sabe, a fé relembra, a cultura escreve e a festa canta, dança e diz a quem venha ver e ouvir" (:28). Há pouca ciência nessas palavras? Que o leitor não se engane com a poesia de Brandão: trata-se de outra forma (aprendida com os mestres populares?) de assumir e expor suas filiações teóricas.

\section{Notas}

1 O termo "Companhia de camponeses" e o verbo "jornadeiam" são usados pelo autor no decorrer do livro para caracterizar os grupos de foliões e as visitas destes às casas durante as jornadas realizadas nos festejos da Folia de Reis. 


\section{Larissa Geórgia Bráulio Moura}

(larissabrauliomoura@yahoo.com.br)

Graduada em história pela Universidade Federal de Viçosa. Mestranda do Programa de Pós-graduação em Extensão Rural da Universidade Federal de Viçosa-MG. Pesquisadora do Observatório da Juventude Rural-UFV.

Sheila Maria Doula (sheila@ufv.br)

Doutora em Antropologia Social pela Universidade de São Paulo. Professora do Programa de Pós-graduação em Extensão Rural pela Universidade Federal de Viçosa-MG. Coordenadora do Observatório da Juventude Rural-UFV. 